\title{
Problems and Outlooks of International Integration of Higher Education
}

\author{
Galina Valerianovna Kashkan ${ }^{1} \&$ Mariya Sergeyevna Egorova ${ }^{1}$ \\ ${ }^{1}$ National Research Tomsk Polytechnic University, Tomsk, Russia \\ Correspondence: Mariya Sergeyevna Egorova, National Research Tomsk Polytechnic University, Lenin ave., 30, \\ 634050 Tomsk, Russia.
}

Received: December 6, 2014

Accepted: January 29, 2015 Online Published: June 29, 2015

doi:10.5539/ies.v8n7p250

URL: http://dx.doi.org/10.5539/ies.v8n7p250

\begin{abstract}
The aim of the study was to identify the major trends related to increasing the role of science in production and society. After the completion of the study it was able to determine the enrollment level for high school graduates into higher education institutions in different countries. It was concluded that the internationalization of a higher education acquires the features of a new stage-integration, as evidenced by the appearance of the appropriate political and legal superstructure integration complex. There were considered systemic symptoms of the world system of higher education. International cooperation is a powerful tool for the world of higher education. It is designed to address a number of urgent tasks. It was concluded that competition between values and models of public, state and social and economic development is one of the key trends of the new millennium. There were determined the tasks of the International Federation of Social Workers which promote international integration of higher education. It was concluded that there was an appearance of new internationalization forms which characterized by cross-border mobility of universities or their curriculums. Program mobility includes distance learning courses offered by foreign universities or joint courses and programs. Mobility of the universities involves opening foreign universities campuses by universities or an establishment of an entirely new institution of the higher education university which shall attract capital of foreign university. Today one can watch the fourth wave of "internationalization of the higher education" which is a reflection of contemporary processes of globalization and internationalization of the economy and society. The internationalization of the higher education is an objective and dynamically developing process. According to many scientists and educationalists of the higher school the internationalization of the higher education acquires the features of a new stage which is integration as evidenced by the appearance of the appropriate political and legal superstructure integration complex.
\end{abstract}

Keywords: education, science, integration, international cooperation, financing

\section{Introduction}

The higher education is the most important social institute which is functioning to meet social demands therefore it rapidly acts on every social changes and processes. A growth of international openness of national cultures and main global trends in human civilization development are uniquely interfered into educational system. Namely, world economic relations, which are constantly branching and acquiring more and more diversified content, are forming a demand in universal professional community who receive their special professional education in national universities. This leads to the fact that the content of national systems of the higher education strives to the so-called "global standards" which are set by global science and technology.

The primary trend which is related to the growth of a science role in industries and society is the enlargement of the higher education scopes.

The higher education becomes more mass. The level of enrollment into higher education organizations in different countries was about average 60 per cent and 84 per cent in North America. There is a boost in a number of undergraduates. Whereas a number of undergraduates in 1960 were 13 million people according to the UNESCO information, it increased almost sevenfold in 1997 with 88.2 million totals (UNESCO, 2000, p. 116).

Another important trend, which has been developing since the second half of the 20th century particularly fast, is a diversification of the higher education into institutional forms, levels and content. A role of a conventional 
university has not decreased only, but grew as well within the conditions of a developing diversification of educational bodies which give knowledge and skills in the sphere of brainwork. They have serious ground to claim the role of centers which would form sociological and cultural environment in particular regions.

The third velocity gaining trend is a trend of the international higher education based on a unique nature of knowledge and mobilization of teamwork of international scientific society. This is shown both through the growing role of international cooperation within activities of national educational bodies and introduction of supranational organizations, programs and foundations. "There is a closest convergence, even a communality of problems, trends, tasks and aims which makes one forget about national and regional differences and peculiarities" in the sphere of the higher education (Global report on education 2006, pp. 32-34).

There is an increasing concern of the government, industries, students and higher education related employers for graduates with practical skills (Billett, 2014, pp. 1-13).

Competing values and models of public, state and social and economic development is one of the key trends of the new millennium. Today this kind of leadership is impossible without advancing human development which is the basis of the formation of the new economy of knowledge. That is why many fast developing states (such as Brazil, Russia, India and China) pay special attention to the modernization and internationalization of national education systems in the process of transition to an innovative economic model (Concept of long-term social and economic development of the Russian Federation until 2020 (2008)).

Over the past three decades, the number of students getting education outside their home country (or "mobile students", according to the UNESCO classification) has increased more than four times (from 0.8 million in 1975 to 3.7 million in 2009). In the period between 1975 and 2004 UNESCO highlights three most notable rises of international student mobility. During the first rise (1975-1980) the total number of mobile students increased by $30 \%$ from 0.8 to 1.04 million people. Next rise was observed from 1989 to 1994 , when the number of mobile students has increased by $34 \%$. There was the third rise by $41 \%$ within the period from 1999 to 2004 (Global report on education 2006, pp. 32-34).

International student mobility has continued to grow over the past ten years. In 2007, the worldwide number of foreign students was 2.8 million, and in 2009 it equaled 3.7 million people. According to a forecast international student mobility will reach 5.8 million by 2020 and 8 million people by 2025 (Tremblay, 2010, p. 117).

Perhaps now, one can watch the fourth wave of "internationalization of the higher education", which is a reflection of contemporary processes of globalization and internationalization of the economy and society (OECD Factbook, 2011-2012, p. 214).

During the past fifteen years, there appeared new forms of internationalization, characterized by cross-border mobility of universities or their curriculums. Program mobility includes distance learning courses offered by foreign universities or joint courses and programs. Mobility of the universities involves opening foreign universities campuses by universities or an establishment of an entirely new institution of the higher education university which shall attract capital of foreign university (Tremblay, 2010, p. 117).

\section{Methodic}

Internationalization of the higher education is an objective and dynamically developing process. According to a number of scientists and luminaries of the higher schools the internationalization of the higher education acquires features of a whole new level which is a process of integration. It is shown by creation corresponding political and legislative suprastructures of an integrative bias. An integration of the higher education appears to be full convergence of national educational systems, their complementarity and a transformation of the higher education into a global social system. However it should be mentioned that the integration of the higher education is a process of combination, not a combination itself (Liferov, 1999, p. 50). The reality shows shapes of such a system which creates achievements, problems and contradictions.

The global system of the higher education can be described as an open social system with non-rigid inter-element links, consistency of the elements themselves and flexibility of normative control. Alongside, it meets the main features of consistency (Materials for the VI session of Inter-agency commission on international partnership in the field of education, 1999).

First of all, the global higher education constitutes a variety of correlated elements of different levels and natures. The following should be referred to these elements: educational bodies making relations with foreign partners and organizations, particular national and regional systems working out a general development strategy for the whole world under the aegis of the UNESCO and the UN, and different international educational organizations and associations promoting merging of the global higher education into the single system. 
Secondly, one can notice introduction of signs of integrity and self-sustainability in regard of economical, political and other global social systems. The foundation for these processes is an existence of universal norms of academic freedom and democracy which traditionally control activity of conventional universities, and international agreements acquiring higher meaning for educational systems, world declarations accepted at international forums and defining development prospects of the higher education and are willingly accepted and carried out by all signatory.

Thirdly, the global system of the higher education has such a feature of consistency as stability which is achieved as a result of a constant reproduction of own structural elements, resources and norms that control its functioning. Moreover, the stability supposes a constant development of the higher education system, its adjustment to the changing conditions of the modern world. Thereupon the crisis of the higher education which is widely spoken and written about a lot is nothing but a sign to change its content, forms and tasks in response to the "challenge of the epoch". It is necessary to note that a successful negotiation of the crisis is probably possible only with alliance of national power and resources upon condition of international solidarity, mutual assistance and support. The crisis boosts the demand in the international integration of the higher education.

\section{Results}

The enlargement of the higher education scopes puts a problem of a quality of the education point-blank. The modern society needs for highly-educated and mobile professionals. And the society itself not only can, but has to encourage competent higher education by affecting the market of young professionals.

There is a challenge of financial support for the growing scopes of the higher education. An increasing number of undergraduates make a lot of educational bodies to decrease costs for modernization of infrastructure, library stocks, international partnership and pedagogical personnel.

The internationalization of the higher education, that meets the growing demands in cross-cultural understanding and caused by the global nature of the modern means of communication and consumer markets, is by all means a prosperous trend. However, mobility of undergraduates and teachers upon the conditions high differences between the economical developments of some countries lead to such a negative trend as brain-drain. A loss of qualified human resources by developing countries and countries in transition is caused but not limited to the academic mobility. It is also resulted by actuation of global migration and by the fact that developed countries intentionally build their migration policy and provide more favorable terms.

The integration of the higher education into the global system in an objective process which should not develop blindfold. The global community can and must see and analyze pros and cons of the process, make major managing decisions regarding its coordination and correction. The main role within the international integration development process belongs to international partnership and such international organizations as the UNESCO.

The international partnership is a powerful instrument of development of the global system of the higher education. It is aimed to solve a number of modern issues, such:

- Following the correspondence of the content and the level of the higher education to the needs of economics, politics as well as social and cultural sphere of the society;

- $\quad$ Alignment of the professional training levels in different countries and regions;

- Enforcement of the international solidarity and partnership in the sphere of the higher education;

- Joint use of knowledge and skills in different countries and on the different;

- Assistance in development of higher education bodies, especially in the developing countries including financing from international foundations;

- Coordination of activities of educational bodies in order to develop the higher education;

- Encouraging of overall improvement of flexibility, coverage and quality of the higher education that promotes elimination of reasons for "brain-drain";

- Motivation for competence among schools of thought and educational systems combined with academic solidarity and mutual assistance.

The international partnership changes own shapes and types of activities, accumulating the opportunities to solve a triune objective: achievement of such a level of the higher education which would meet the needs of the modern society; alignment of national educational systems level; training of skilled personnel for national economics. There is an increasing role and meaning of international organizations, foundations and programs in the field of education and science. 
A comprehensive policy in the field of the higher education has been developed and carried out in the European Union for decades and so supranational institutions of coordination and management have been formed. There have been developed and adopted seven conventions on reciprocal recognition of secondary education certificates, studies and their periods, diplomas and degrees concerning higher education which constitute a legal framework of integrated process in the sphere of the higher education in the UN.

The "National doctrine on the education in the Russian Federation" states that the state is aimed to provide "integration of the Russian system of education into the global educational environment considering homeland experience and traditions, entrance to the market of educational services, extensive participation of educational bodies and pedagogues in educational programs of international organizations and communities" (National doctrine of education in the Russian Federation, 2000, p. 10).

It is required to find the best options of consecutive integration of the Russian higher education system into the global system of the higher education, save everything precious that belongs to the Russian higher education system, and at the same time to implement some alterations required up to date with consideration of international experience which shall give an option to provide the development prospects for Russia in the new century. If makes a comparison he can see that educational expenditure level in America is considerably higher, than in other member nations of OECD altogether, educational costs for a person in the United States increases as quick as in a lot of other countries. Russia falls behind these figures (Wolff et al., 2014, pp. 1-21).

\section{Consideration}

In today's world the importance of education as the most important factor in the formation of a new quality of economy and society increases with the growing influence of human capital. In the XXI century only those states will be able to remain independent which will stand the intellectual and technological competition.

A number of significant changes have happened over the last decade in the Russian higher education. There has been introduced a new parallel structure of the higher education which is a combination of educational programs of different durations and orientation related to educational direction (Grebnev, 2003, pp 4-25).

Nowadays, an important thing is to provide real multiple level system of the higher education including the experimental development (in accordance with the Bologna Declaration of 1999 "On creation of the European Higher Education") of multi-stage structure of the Russian higher education compatible with the European system of higher education (Klyachko, 2002, pp. 48-55).

Currently most of the universities have appeared to be not ready to reorient education towards qualitative changes in the forms and methods of development of intellectual capacity and human capital. It should be emphasized that alongside with a change in the system of education in modern society there is a change of objectives for education and development of science (Federov, 2005). Some researchers believe that there is a task of changing the principle of education and science development itself, taking into account the requirements of integration. It exactly the way where one can find solutions for critical contemporary social and economic problems, particularly related to the provision of quality education, conservation and development of promising research directions (Putin, 2002).

To the present time in Russia, due to the significant reforms in the political and economic spheres, caused by the need to develop the system of state support for the population, broadening and deepening of the problematic field of social work there was a detachment of an important new component of general and vocational education which is social education, the content of which involves professional socialization, i.e. a preparation of subjects of social work. This kind of activity is impossible without contact between its performers, which is why the International Federation of Social Workers (IFSW) confronts themselves with the following tasks:

- Promote the development of social work as a profession through cooperation with consideration of professional values, standards, ethics, human rights, education, and working conditions;

- Strengthen the participation of social workers in the formation and implementation of social policy;

- Broaden and deepen the educational programs in the "Social Work" specialty; universally implement its values and professional standards;

- $\quad$ Promote cooperation of social workers of all countries ;

- Establish and maintain relations with international organizations dealing with social development and welfare;

- $\quad$ Improve the system of social education (Dodds, 2002, pp. 54-59). 


\section{Conclusion}

The international character of the modern education is particularly expressed in introduction of a trend for international "division of labour" in the sphere of professional education, increase of academic mobility of students and increase of a number of foreign students in the world. Educative practice of advanced countries have specialized educational programs, institutes and other mechanisms to educate foreign students (who mostly come from developing countries). Pedagogical science should properly meet these trends. A format of distance learning and on-line technologies is getting a widespread acceptance which promotes an integration of Russia into the global universe (Self, 2013, pp. 36-45; Wunder, et al., 2013, pp. 4-15).

The communities that have different projects that promote development of education should be involved as well (Huber \& Mafi, 2013, pp. 310-332).

In Russian universities there is little realization of joint educational programs, including foreign languages, international collaborative researches aimed to internationalization of the content of curriculum. In this regard, another very important area is the creation of bilateral and multilateral programs with foreign universities, and especially joint master's and postgraduate programs with leading universities in Europe. Graduates of these programs receive diplomas of two, and sometimes three universities, undergoing training, both in Russia and in the partner universities abroad. This kind of communion to several schools in the national education significantly increases human capital and competitiveness of students.

It was failed to consider many aspects of a fruitful and beneficial cooperation for all universities of in Russia and foreign countries in this study. Further research in this direction can open the prospects of this cooperation and the results obtained during the implementation of joint programs.

\section{References}

Billett, S. (2014). Integrating learning experiences across tertiary education and practice settings: A socio-personal account. Educational Research Review, 12, 1-13.

Dodds, I. (2002). Global problems of social work at the international level. Social work (Popular Science Journal), 2, 54-59

Federov, I. B. (2005). Integration of education and science: Key aspects. Higher education nowadays, 6.

Global report on education. (2006). Comparison of global statistics in the sphere of education-Institute of statistics of the UNESCO (pp. 32-34). Montreal, 2006.

Grebnev, A. (2003). Russian education reflected in the demography. Issues of the economics, 7, 4-25.

Huber, M. M., \& Mafi, S. L. (2013). Education par excellence: Developing personal competencies and character through philanthropy-based education. Journal of Accounting Education, 31(3), 310-332. http://dx.doi.org/10.1016/j.jaccedu.2013.07.001

Klyachko, T. (2002). Modernization of the Russian education: Problems and solutions. Home notes, 2(3), 48-55.

Liferov, A. P. (1999). Integration processes in the global education: The main trends. International magazine on the problems of education (p. 50).

OECD Factbook. (2011-2012). How many students study abroad? Economic, Environment and Social Statistics (p. 214).

Putin, V. V. (2002). Everyone is worried with problems of education: a report at the VII session of the Russian Union of Principals. Higher education nowadays, 12.

Self, S. (2013). Utilizing online tools to measure effort: Does it really improve student outcome? International Review of Economics Education, 14, 36-45. http://dx.doi.org/10.1016/j.iree.2013.03.001

Tremblay, K. (2010). Internationalization: Forming of strategies in the national context. International organization newsletter, 3(29), 117.

UNESCO. (2000). World education report (p. 116). Paris.

Wolff, E. N., Baumol, W. J., \& Saini, A. N. (2014). A comparative analysis of education costs and outcomes: The United States vs. other OECD countries. Economics of Education Review, 39, 1-21. http://dx.doi.org/10.1016/j.econedurev.2013.12.002

Wunder, T., Elliott, D. R., \& England, S. (2013). Is distance learning really a substitute for on-site learning? Perceptions of faculty who teach undergraduate economics using both formats. International Review of Economics Education, 14, 4-15. 


\section{Copyrights}

Copyright for this article is retained by the author(s), with first publication rights granted to the journal.

This is an open-access article distributed under the terms and conditions of the Creative Commons Attribution license (http://creativecommons.org/licenses/by/3.0/). 